\title{
Tick-borne parasitic diseases in cattle: Current knowledge and prospective risk analysis related to the ongoing evolution in French cattle farming systems
}

\author{
Monique L'Hostis ${ }^{a *}$, Henri SEegers ${ }^{b}$ \\ ${ }^{a}$ UMR ENVN/INRA 1034 « Interactions Hôte-Parasite-Milieu », École Nationale Vétérinaire \\ de Nantes, BP 40706, 44307 Nantes Cedex 03, France \\ b UMR ENVN/INRA 708 « Gestion de la Santé Animale », École Nationale Vétérinaire \\ de Nantes, BP 40706, 44307 Nantes Cedex 03, France
}

(Received 11 December 2001; accepted 10 June 2002)

\begin{abstract}
Parasitic diseases, like babesiosis and theileriosis are transmitted by ticks: their occurrence is therefore linked to the size of the tick stock and the seasonality of the vectors. Babesia divergens bovine babesiosis transmitted by Ixodes ricinus is widespread and often reported in France. Serological prevalence is high, ranging from 20 to $80 \%$ according to the farms. Clinical incidence is low: around $0.4 \%$ for the whole cattle population. The endemic situation is unstable and clinical cases occur more frequently with farming system modifications. I. ricinus is a tick essentially found in woodlands and so, for the most part, is found in closed rural areas. The situation of the other bovine babesiosis (Babesia major) and theileriosis (Theileria orientalis) is not well documented in France. However, the epidemiology of parasitic diseases is changing, especially because of changes in the environmental characteristics, i.e. both farm and herd management conditions and also climatic conditions. These modifications can provoke an increase in the tick stocks, an increase in the contact rate between cattle and ticks, and an increase in the contact rate between cattle and the wild fauna, especially deer. This results in likely modifications of the endemic situation, with a higher risk of clinical babesiosis in the medium term.
\end{abstract}

tick-borne parasitic disease / cattle / farming system / climatic change / France

Résumé - Parasitoses bovines transmises par les tiques : état actuel des connaissances et analyse prospective du risque en relation avec l'évolution des systèmes d'élevage en France. Les protozooses telles que les babésioses et les theilerioses bovines sont transmises par des tiques, leur présence est donc fortement liée à la présence et à la dynamique saisonnière des tiques. Ces maladies sont

*Correspondence and reprints

Tel.: (33) 2406876 97; fax: (33) 2406877 51; e-mail: lhostis@vet-nantes.fr 
présentes en France, et certaines ont une réelle importance économique. La babésiose bovine à Babesia divergens, transmise par Ixodes ricinus est largement répartie en France. La prévalence sérologique est élevée, comprise entre 20 et $80 \%$ selon les exploitations. L'incidence clinique est de $0,4 \%$. Des épisodes cliniques sont fréquents lors de modifications dans l'élevage. L'équilibre, selon le modèle établi pour d'autres protozoaires, est qualifié d'instable. Ixodes ricinus est une tique de bois et forêts qui survit sur les pâtures. La situation des autres babésioses et theilérioses présentes en France est moins connue. L'évolution de la structure des élevages, notamment la désintensification avec constitution de troupeaux sur de larges surfaces, de même que la présence des friches, est, selon toute vraisemblance, susceptible de provoquer une recrudescence ou une émergence de maladies à vecteurs en raison de la présence des animaux domestiques dans des biotopes moins contrôlés où les contacts avec les vecteurs sont plus fréquents. De plus, les animaux sauvages jouent un rôle de réservoir, soit de vecteurs (arthropodes), soit d'agents pathogènes parasitaires, transmis par ces vecteurs. En revanche, la moindre demande en performance d'élevage pourra diminuer les effets de ces modifications. L'équilibre instable de cette épidémiologie se traduira, par des épisodes cliniques plus nombreux dans les régions ou seront effectuées ces modifications des systèmes d'élevage.

maladie parasitaire transmise par les tiques / bovin / système d'élevage / changement climatique / France

\section{Table of contents}

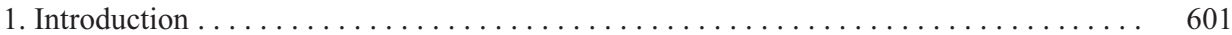

2. State of the knowledge of tick-borne parasitic diseases in France . . . . . . . . . . . 601

2.1. Tick-borne protozoal diseases reported in France. . . . . . . . . . . . . . . . 601

2.1.1. Babesia divergens . . . . . . . . . . . . . . . . . . . . . . 601

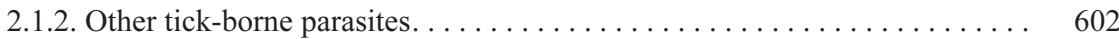

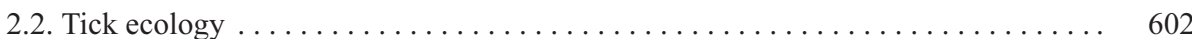

2.3. Unstable situation for tick-borne parasitic diseases $\ldots \ldots \ldots \ldots \ldots \ldots \ldots \ldots . \ldots 63$

3. Trends in the evolution of French cattle farming systems . . . . . . . . . . . . . . 605

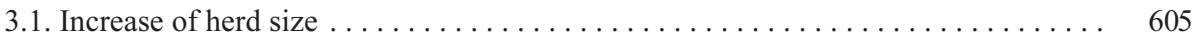

3.2. The use of lower levels of external production factors . . . . . . . . . . . . 605

3.3. Reverse movement towards less intensive systems $\ldots \ldots \ldots \ldots \ldots \ldots \ldots \ldots . \ldots 65$

3.4. Further need for improvements in labour productivity . . . . . . . . . . . . . . . 606

3.5. Extra demands in certified production and organic farming systems . . . . . . . . . 606

4. Prospective risk analysis on tick-borne parasitic diseases. . . . . . . . . . . . . . . 607

4.1. Risk of an increase in tick stocks . . . . . . . . . . . . . . . . . . . . 607

4.2. Risk of increased contact of cattle with ticks and the expanding wildlife ....... 608

4.3. Risk of increased exposure to densified tick-borne parasites and of increased infection and clinical cases . . . . . . . . . . . . . . . . . . . . . . . . . . . . . . 608

4.4. Changes in prevention . . . . . . . . . . . . . . . . . . . . . . . . . . . . . 609

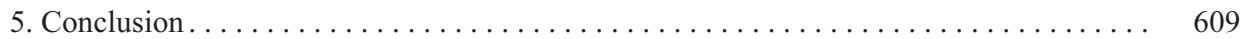




\section{INTRODUCTION}

Tick-borne parasitic diseases occur throughout the world, especially in tropical and subtropical areas, but they are also prevalent in many temperate areas, such as northern Europe and France. Ticks generate direct effects in cattle: milk production and growth decrease. However, in northern Europe, transmission of tick-borne parasitic diseases, like Babesia and Theileria represents the main pathologic effect of the prevalent ticks $(12,37]$. The presence, dynamics and amount of parasite stock in ticks exert a major influence on the kinetics of transmission of tick-borne parasitic diseases (37]. A three-host-stage tick (like Ixodes ricinus) spends practically its whole life (three years) on the ground, and only three weeks on its hosts. Therefore, the most limiting circumstances for its survival are the abundance and the stability of the vegetational cover [35].

Many factors possibly contribute to the emergence and re-emergence of tick-borne diseases: drug resistance, genetic evolution of the vector-borne pathogens, and so-called global change (economic, social and environmental factors) [36]. Global change includes changes in the average climatic trend, climate variation, land cover and land use. Simultaneously, farming systems and especially pasture practices also evolve and, together, they modify the dynamics of the ecosystems. Thereby, environmental factors induce large modifications in the stock and repartition of vectors in the field, particularly of ticks [45].

Prevalence and analytic epidemiology of bovine tick-borne parasitic diseases in France are not well described. For bovine babesiosis induced by Babesia divergens, some data have been collected [24]. Currently, cattle farming systems often evolve towards possible larger exposure of cattle to ticks.

This paper is aimed at: (i) reporting the state of knowledge about tick-borne para- sitic diseases in France, (ii) summing up recent and current trends in the evolution of French cattle farming systems, (iii) discussing the possible prospective evolution of these tick-borne parasitic diseases in France in the coming decade.

\section{STATE OF THE KNOWLEDGE OF TICK-BORNE PARASITIC DISEASES IN FRANCE}

\subsection{Tick-borne protozoal diseases reported in France}

Babesiosis and Theileriosis are the only known tick-borne parasitic diseases in Europe. Bovine babesiosis is widespread in north-western, south-western and central France, especially in bocage areas [24]. Babesiosis is due to tick-borne intraerythrocytic parasites of the Babesia protozoa genus. In France, two Babesia species are responsible for bovine babesiosis: Babesia divergens transmitted by Ixodes ricinus and Babesia major transmitted by Haemaphysalis punctata. Babesia divergens is a highly pathogenic species, often reported by veterinary surgeons to be involved in clinical disorders $[1,24]$. On the contrary, infection due to Babesia major is considered as almost signless [30]. Evidence for the respective roles of both parasites has been reported by L'Hostis et al. [24]: out of 424 blood samples (from suspected clinical cases), collected in the whole country, 374 contained $B$. divergens and only one $B$. major. The presence of Theileria sp. in France was first reported by Sergent et al. in 1926 [42].

\subsubsection{Babesia divergens}

The annual clinical incidence of babesiosis due to $B$. divergens varies among areas. The variation was from 0 to $2.1 \%$ for French "départements" with a mean annual clinical incidence of $0.4 \%$ in the whole cattle population. Most cases occur in the spring (May or June), and the rest 
occur, to a lesser degree, in September and October. Data also support the hypothesis of inverse age resistance: $72.6 \%$ of affected cattle were adult cows (more than three years old) [24]. Seroprevalence studies allow to better understand the epidemiology of babesiosis. A serological study was carried out on four farms in western France, based on monthly sampling [26]. Half of the animals were already positive in the autumn, at the beginning of the study. In all four herds, the percentage of positive animals decreased during the winter, and increased during the spring. The calves showed seroconversion during the first pasture season and their mean antibody level reached the level of the older cattle during the second pasture season. The mean antibody level of the heifers and dairy cows was high and was consistent with the variations in tick activity [26]. Annual clinical incidence was low on the four farms: only three dairy cows developed clinical babesiosis over the two years $(n=236)$. Although, the annual sero-conversion incidence was high. Most seropositive animals showed at least one antibody peak at some time during the two year period, but some bovines presented two to five peaks. In summary, cattle experience asymptomatic infections several times during the year, mostly during the spring and autumn [26].

\subsubsection{Other tick-borne parasites}

The general situation of other tick-borne diseases in domestic ruminants is still largely undocumented in France, mainly because of the low pathogenicity of their agents rather than their low prevalence. Among them, Babesia major bovine babesiosis transmitted by Haemaphysalis punctata was recorded in the French Lot [30] and Charente [25] departments located in south western France. Babesia bovis bovine babesiosis transmitted by Boophilus annulatus has been found in Europe since 1955 [43] and is present in Corsica [48]. Babesia bigemina is probably also present (unpublished results), since Boophilus annulatus and Rhipicephalus bursa, its vectors, are widespread for example in Spain and North Africa where Babesia bigemina bovine babesiosis is present.

Theileria orientalis bovine theileriosis (buffeli/orientalis/sergenti group) transmitted by Haemaphysalis punctata has been found in France: in Corsica [48], in an island in French Brittany under an asymptomatic form, and is suspected in the southern Alps (unpublished results). In the south and the west of France, this is probably more common than one thinks. Moreover, in 1926 Sergent et al. [42] already described the presence of Theileria mutans in cattle in the Aubrac. Due to the confusion in the identification of the genus Theileria, T. mutans could have been Theileria orientalis. B. major and T. orientalis are low pathogenic parasites that are certainly present in France and the opinions of veterinary surgeons seem to indicate that the suspected areas could be widespread in southern and western France (unpublished results). Numerous cattle are probably asymptomatic carriers as in the case of $B$. divergens.

\subsection{Tick ecology}

Tick seasonal dynamics exert a major influence on the dynamics of transmission of tick-borne pathogens [12]. Two species of ticks have an incidence on tick-borne parasitic disease in bovines in France: I. ricinus and $H$. punctata.

I. ricinus (vector of $B$. divergens) is a three-host tick; each stage feeds once on a separate host. I. ricinus is able to infest mammals, birds and reptiles. But the larvae, nymphs and adults are each more or less confined to different groups of hosts: adults mostly on large animals (wild and domestic ungulate: deer, cattle); nymphs on large mammals and micromammals, and larvae primarily on micromammals and birds [34, 37]. The larvae and nymphs have 
no particular parasitic preference whereas the adults are more selective concerning certain mammals. It appears that Cervidae are the chief hosts for engorged female ticks and they may play quite an important part in maintaining female ticks in an area $[16,34,39]$. The permanent presence of I. ricinus depends on deer in woodland or forest areas and the domestic ungulates (cattle and sheep) in open rural areas. This biological cycle can vary from $1-6$ years depending on the concentration of the hosts [35], its distribution is dependent on the proportion of active nymphs which find a host [50].

In its various stages, $I$. ricinus spends a total of about three weeks in its hosts; the rest of its life, about three years, is spent on the ground, this time being taken up in development, quiescence and host seeking $[27,35]$. I. ricinus is common in NW Europe; it occurs in the woodlands (beech tree or deciduous oak), but it is also recovered in closed rural areas and in bocage areas, in western France [17, 25, 37]. In pastures, $I$. ricinus is able to maintain its presence with difficulty. However, pastures located in the close vicinity of a woods, whatever their soil type or vegetation are at six- to seven-fold increased risk than pastures without a woods in the close vicinity and consisting of seeded grass species [32]. At the moment, in open rural areas, the biological cycle has been slowing down because there are only a few hosts for the adult stages [37]. I. ricinus constitutes an extremely prolific reservoir of $B$. divergens due to the type of transmission. An infected tick, through its descendants, ensures the longevity of the infection in a biotope for at least 5-6 years [11].

H. punctata (vector of B. major and T. orientalis) is a three-host tick found throughout Europe, from Spain to southern Scandinavia. The adults are primarily parasites of sheep and cattle, but also of wild ungulates (deers). The larvae and nymphs are most commonly found on small mam- mals, birds and reptiles. $H$. punctata occurs in widely differing environments, for example relatively cold and humid coasts [20, 27]. In France, this tick is widespread in several microhabitats, such as the Atlantic areas and the southwest (unpublished results). Its life cycle is usually completed within three years, and under favourable conditions may be completed within one year.

\subsection{Unstable situation for tick-borne parasitic diseases}

The exposure of young cattle to sufficient ticks infected with Babesia (inoculation rate) during their life, without clinical babesiosis, can ensure a strong protection. For babesiosis (Babesia bovis and Babesia bigemina), theileriosis (Theileria parva) and anaplasmosis (Anaplasma marginale), antibody prevalence and inoculation rate have been used by some authors [4, 28, 29, 38 ] as an indicator of endemic stability or instability. Two epidemiological cases are described. If we consider the tick attack rate and the prevalence of antibodies to tick-borne pathogens in herds (Fig. 1) [38]:

- an endemic stable situation may arise where many cattle develop immunity to the parasite, without causing clinical babesiosis. This occurs in herds in which over $75 \%$ are seropositive. There is a low risk of clinical disease;

- endemic unstable situations arise when cattle are exposed to a lower tick attack rate. This occurs in herds in which less than $75 \%$ are seropositive. These herds are at significant risk of clinical disease, since there is still a number of susceptible cattle. In a first case, there is still a high inoculation rate of infected ticks, when the seroprevalence is over $10 \%$ the risk of clinical incidence is then high. In a second case, i.e. in herds in which less than $10 \%$ of the cattle are seropositive, cattle are susceptible, the inoculation rate is almost low, and therefore the risk is low, but when the 


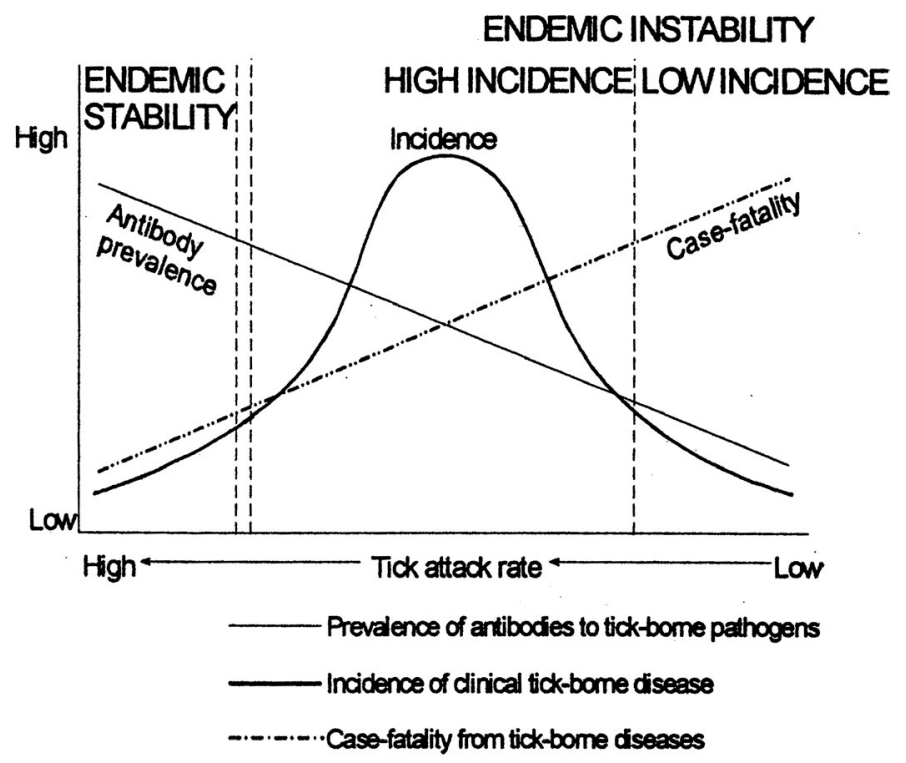

Figure 1. Conceptual model of the relationships between infection challenge by ticks, disease incidence, case fatality and antibody prevalence in tick-borne disease infections. After Perry and Young [38].

clinical case appears, case-fatality rate is then high.

With this model, it is easy to understand that when the tick attack rate changes in a herd, the endemic situation varies in one direction or another.

Most often, in France, B. divergens produces few clinical cases. However, certain herds exhibit clinical cases more frequently throughout the seasons. Their occurrence is still partially unexplained; one hypothesis is the existence of insufficient contact between the parasite and the host, due to the irregular presence of the vector in the pastures. The limited contacts between the hosts and the parasite provoke immunological ruptures in the host. When cattle are again in contact with the parasite (for example when they change pastures), there often is an outbreak of serious clinical cases.
Over the course of a prospective study, L'Hostis et al. [26] showed that $B$. divergens prevalence as judged by serology, varied between $20 \%$ and $80 \%$. Most of the French areas had a markedly high seroprevalence for $B$. divergens, but these values are not enough to confer stability, and most of the farms are in an endemic unstable situation for the clinical disease.

Does the model of "endemic stability or instability" apply for all the tick-borne parasitic diseases? If so, we can state that the endemic situation is unstable in France for the two bovine Babesia infections and perhaps also for bovine Theileria infection. In an endemic unstable situation, the farms have a significant risk of clinical disease, since there is still a sufficient number of susceptible animals and inoculation rates from infected ticks are high enough to cause disease. In these cases, outbreaks of 
clinical babesiosis often occurs when there are modifications in the ecosystem [37].

\section{TRENDS IN THE EVOLUTION OF FRENCH CATTLE FARMING SYSTEMS}

\subsection{Increase of herd size}

In France, over the past 25 years, cattle production systems have evolved, with a strong decrease in the number of farms and a simultaneous concentration of cattle into larger-sized herds: from approximately 800000 farms to 275000 and from 29 to 73 heads on average per herd (approximated from [41]). In the future, the increase of the average herd size will probably continue (see below about the need for improving labour productivity). However, the strength of the phenomenon will depend on European beef meat consumption and demand levels and also on more political issues related to the recognition of - and incentives to - multifunctionnality of cattle farming in Europe [19].

\subsection{The use of lower levels of external production factors}

During the last decades, a widely generalised movement towards intensification was observed in whatever the cattle farming system. The main point consisted in improving the productivity of the most limiting factor, which was initially land and progressively became labour [47]. This productivity improvement was mainly obtained by using still higher levels of external inputs (purchased concentrates; chemical fertilisers, seeds and phytosanitary drugs for an intensive roughage production based on Italian rye-grass and maize crops) and by reaching high individual animal productivities (milk yield per dairy cow-year or daily gains in growing young bulls...) in combination with high stocking densities on the roughage-crop area of each farm. High individual animal performance was obtained by the use of rations with high-energy concentration and by the efficient genetic improvement for quantitative production traits $[8,14,33]$.

Since the second part of the 1980s, under new CAP (Common Agricultural Policy) constraints, which have set de facto limits in the allowed production volume for a given farm (milk quotas and quotas in the number of suckler cows eligible for subsidies), the dominant trend is now to produce the allowed volume of products at lower costs. Therefore, farmers try (1) to improve the efficiency of the production process, but also (2) to reduce the global cost of purchasing production factors ("low input systems" or "input economy"): i.e. by reducing the external purchases and/or using more internal resources (less concentrates and maize silage and more pasture or grass silages, better utilisation of manure or slurry, and fewer purchases of chemical fertilisers) [2]. In addition to this trend, recent crises in the livestock sector (BSE, dioxins...) have led more farmers to look for autonomy and higher traceability in their feeding system.

\subsection{Reverse movement towards less intensive systems}

More recently, in a large number of areas, the pressure on land has become lower and enlargement of the land resource of the remaining farms has become easier. Systems have evolved towards having only a small percentage of silage-maize in the roughage crop area, a lower stocking density, and a larger part of grass (pastured or cropped into hay or silage) into the rations. In dairy farms, the resulting production levels of animals are most often not further increasing and a decrease is sometimes observed. Moreover, differences in milk yield per cow-year are only responsible for 
a small part of variation in the annual profit of dairy farms [40].

The birth of low input and grass-based systems, maximising the length of the grazing period in western France can also be mentioned [3]. In such systems, cows can still have a high genetic merit for milk, be frequently Holsteins, and nevertheless perform from 1000 to $1500 \mathrm{~kg}$ of milk per lactation under their genetic level. These systems aim at maximising the pasture period and minimizing the use of cropped roughages. However, it does not seem to be relevant to speak about "extensified or extensive" systems: levels in stocking density are almost still between 1 and 1.4 livestock units/ha of grassland.

\subsection{Further need for improvements in labour productivity}

Systems will still move towards higher animal/manpower ratios and, more and more, farmers will expect to find, in their professional activity, work conditions and free time equivalent to those provided to other people [9]. Moreover, given the CAP perspectives, the part of the farm income originating in sales of products will be reduced through lower market prices. A global consequence is that a further search for an improvement of labour productivity will still remain a strong trend in the future.

For management of herd health, the translation will be less surveillance to detect disease and less time available to implement preventive actions. Therefore, the farmer's expectations widely consist in simplified solutions, like multi-targeted and long-acting preventive techniques (pour-on, bolus presentations of anthelmintic drugs, for example). Simplified management will also be implemented in feeding and pasture management: no respect of transitional phases, a decrease in the use of rotational paddock grazing (previously more common during the spring), and, sometimes gathering of several types of grazing animals together at certain periods (young heifers, pregnant heifers and dry cows for late-autumn pasturing for example). A more extreme, but not uncommon situation is complete outdoor wintering for heifers or suckler cows [15].

For the roughage-production system itself, the main translation of higher labour-productivity needs will be more permanent and long duration grassland pasturing. The result can also be giving up certain difficult or poorly productive land parcels, for instance slope pastures and wet meadows in the centre of France or mountain and semi-mountain areas, and also for instance, rangelands more in the Mediterranean areas. Such land parcels are then quite rapidly colonised by a modified flora and are progressively invaded by ligneous species, resulting in afforestation and more closed landscapes [10]. During intermediate phases, cattle can still continue to graze on semi-colonised grasslands.

On the contrary, another way to highly improve labour productivity is to go further on towards intensification and mechanisation. The most noticeable example is provided by the dairy farmers who choose robot-milking equipment [49]. This equipment will reduce the ability of the farming system to rely on the pasture, due to the need to keep the herd of cows indoors for longer periods to provide sufficient time to have all the cows milked (most often the goal is to reach more than two milking times per day for each cow).

\subsection{Extra demands in certified production and organic farming systems}

Even if no specific development here is given to this aspect, it is, of course, necessary to mention a certain expansion of specific farming systems. The reduction of the use of antibiotics and anthelmintics is an increasing demand of consumers and distributors in the commodity chains, to limit 
objective and subjective risks related to residues for the consumer and for the environment. This kind of expectations or requirements are often taken into account by GP (good practices) charters or certification specifications. Organic farming has also been rapidly expanding since the last crises (BSE, dioxins, ...). Specific rules prohibiting the systematic treatment with chemical drugs apply to these recognised systems and during their conversion period.

In summary, cattle systems will become more diverse than they have been in the past because classical intensified systems will also remain next to the modified systems. Main trends of new context which have to be taken into account for assessing consecutive modifications in the risk for tick-born parasitic diseases in cattle are the following:

- larger herds with lower levels of available manpower;

- larger use of grass and long duration grasslands;

- where feasible, longer grazing periods, with often simplified approaches in paddock rotations;

- more possible contacts with wildlife;

- animal performance at easier manageable levels (lowered performance);

- demand for managerial prevention more than chemical prevention and for complying GP, especially in implementing curative treatments.

\section{PROSPECTIVE RISK ANALYSIS ON TICK-BORNE PARASITIC DISEASES}

Changes in land use and land cover will contribute both to modifications in the structure and function of the ecosystems. Modification of ecosystems themselves will result in the possible modification of the epidemiology of tick-borne parasitic diseases.

\subsection{Risk of an increase in tick stocks}

The increasing low levels of available manpower and the growing use of grass and long-duration-grassland pastures will result in more closed landscapes areas and substantial changes of the ecosystem in a non negligible part of the country. Agricultural improvement is traditionally considered as bringing up a significant reduction in tick populations. However, the depth of vegetation cover varies over an area, and when the tick is present in an area, its density is positively correlated with the depth of the cover of vegetation. In fact, humidity is the explanatory factor for the relation between the amount of cover and tick population density, particularly I. ricinus [35]. Consecutively, any patch of poorer cover limits the total population, given the fact that patches are scattered, some of the ticks only resist under the better covered areas. On a pasture, when an ecosystem is on the way to becoming more closed, each newly developing patch of ligneous vegetation becomes closer to another one, and, secondarily, increases tick survival, and thereby, also, the prevalent tick stock.

So, humidity through vegetation modulates the ability of the land to support the tick population. Moreover, global change, including environmental modifications like atmospheric warming, will also play a role. The influence of global warming on the transmission of parasitic diseases requires further research. An increase in temperature may allow vectors to migrate into new areas or to allow a significant development of parasites where sometimes previously, ambient temperatures were too low [6]. For example, in northern France, canine babesiosis (Babesia canis transmitted by Dermacentor reticulatus) is more widespread than a few years ago (L'Hostis, unpublished results). In the same way, the tick like Boophilus annulatus and the Rhipicephalus bursa vector of Babesia bovis and Babesia bigemina recorded in 
Corsica and in Spain have the possibility to migrate towards southern areas of France.

Tick stocks will increase, but will also become more scattered in some areas, like some vectors of human diseases [22]. So, the distribution and dynamics of tick-borne parasitic diseases, which are strongly interconnected, will also evolve.

\subsection{Risk of increased contact of cattle with ticks and the expanding wildlife}

Not only the tick stocks will increase, but also the depth of the cover of vegetation will generate more contact between domestic animals with ticks. In fact, in the future, cattle will graze more on pastures near the hedges, where the ticks live. On the contrary, the decrease of the stocking density of cattle due to new management trends can provoke a low decrease of the cattle hosts available for the adult ticks.

However, the enlargement of closed landscapes will promote the emergence of empty and adapted areas for the installation of wildlife, particularly deer, like the "red deer" (Cervus elaphus) but especially "roe deer" (Capreolus capreolus). Wild fauna, and particularly, deer, play an important role in maintaining and in amplifying the tick population as a whole $[16,39]$. The part attributable to wild fauna is larger than that attributable to the farm stock in maintaining the tick population on a grazing pasture. It appears that hares and roe deer are the chief hosts for female ticks, and the domestic animals are considered as alternative, but not very effective and adapted, tick hosts in the pastures [34].

An increase of tick hosts (roe deer for example) might influence the figures; and the expansion of the tick population might actually be underestimated as might be tick-borne diseases. The proximity of wildlife and domestic ruminants, results in the transmission of ticks, and perhaps infec- tious agents (Babesia or Theileria) from domesticated reservoir populations to sympatric wildlife and conversely [46]. Several Babesia species found in the Cervidae have been described. There is epidemiological evidence that $I$. ricinus is a vector of Babesia capreoli, as well as for other deer Babesia [13]. On the contrary, $B$. divergens is experimentally infective for Cervidae [23]. In France, no data are available, but some questions have arisen concerning the real specificity of deer and domestic ruminant Babesia In fact, the situation for tick borne parasitic-diseases in Cervidae, as reservoirs for cattle, remains relatively unknown.

\subsection{Risk of increased exposure to densified tick-borne parasites and of increased infection and clinical cases}

In France, it seems that, regarding bovine babesiosis, the endemic situation is unstable, with a serological prevalence varying between 10 and $75 \%$. According to Mahoney [28], high risk farms were considered endemically unstable with seroprevalence varying between 10 and $75 \%$. These farms have a significant risk of disease since there still is a sufficient number of susceptible animals and the inoculation rates from infected ticks is high enough to cause clinical disease [38]. This results in a higher risk of clinical disease in the medium term, and, perhaps in a lower risk of clinical disease in later life. In fact, the expected increase of exposure to the infected tick stock, can lead to an endemic newly stable situation, when a sufficient proportion of the herd will have developed immunity to commonly present Babesia divergens.

The increase of tick burden on cattle can have an immunological depression effect, like an immunological modulation in the host, and then enhance the development of other diseases, principally in the transmission of tick-borne disease-causing agents 
$[31,51]$. For example, in France, ticks are the hosts of some other pathogenic agents in cattle, like Anaplasma marginale and Anaplasma (Ehrlichia) phagocytophila transmitted by I. ricinus. Some clinical episodes have already been recorded for example in Brittany $[7,21]$ on reconstituted livestock after sanitary stamping out.

Some parasites such as Babesia or Theileria are very specific for their hosts, like $B$. divergens in cattle, nevertheless, in some conditions, these parasites are observed on another species hosts. For example, in experimental conditions, $B$. divergens is easily maintained on sheep [5]. In the same way, $B$. divergens $[18,44]$ and Theileria sp. (L'Hostis, unpublished results) can affect immunosuppressed humans.

\subsection{Changes in prevention}

Clinical cases are, for most of them, in relation with an imbalance between the host and parasite. The tick burden, and then, the inoculation rate will increase in the future. In the actual model of sustainable agriculture, the general use of chemicals, and therefore of specific antibabesial drugs such as Imidocarb (Carbesia), ScheringPlough Vétérinaire, Levallois Perret, France) and acaricides, will decrease, and then the inoculation rate will increase. But, it is possible that fewer or lower numbers of cattle in a pasture minimise the risk of clinical cases. Will these modifications counter-balance each other? We think that no: there is too much imbalance in favour of the parasite. Case fatality will also tend to increase, especially since herd surveillance by farmers is becoming less strict.

In this context, farmers wish to apply specific prevention measures that should be efficient, cost-effective and with a limited interference period, to be in agreement with the new aspects of farming. The ideal solution would then be the production of an anti-babesiosis vaccine with only one injec- tion for the animal's whole life. Since such a vaccine will not be available in the coming years, we can expect babesiosis clinical cases to rise, before possibly reaching a balance again in a few years, unless the landscape, the animals and the farmers change too dramatically.

\section{CONCLUSION}

Epidemiological research is essential in providing updated knowledge about livestock parasitic status, particularly for tickborne diseases. Currently, only some $B$. divergens bovine babesiosis data are available in northern Europe. Information on the other tick-borne pathogenic diseases (B. major, T. orientalis) is very scattered and poor.

An appropriate tool to decide preventive measures of importance for animal production and management is the analysis of the immunological and parasitological status of herds in relation to $B$. divergens and others. However, such analysis only expresses the final result of the complex "host-parasite-tick" interactions, adding little information to define the precise role played by the different factors involved.

In conventional and less intensive cattle farming systems, it is necessary to provide new and updated data, collected in different geographical and climatologic areas: parasitic prevalence, seroprevalence, clinical incidence, inocution rate of Babesia by ticks...

It seems, that a number of parasitic tick-borne pathogens have similar epidemiological endemic situations, like the tropical Babesia species, temperate Babesia species and Theileria species. Therefore, some models concerning tropical parasites may be of interest for temperate parasites. 


\section{REFERENCES}

[1] Brion A., Les piroplasmoses des grands animaux en France métropolitaine, Ann. Parasitol. 22 (1947) 296-313.

[2] Brocard V., Le Cœur P., Le Lan B., Losq G., Chardigny T., Dix ans de travail sur la réduction du coût alimentaire en élevage laitier en Bretagne, 7es Rencontres Recherches Ruminants, 6-7 décembre 2000, Paris, pp. 35-38.

[3] Brunschwig P., Veron J., Perrot C., Faverdin P., Delaby L., Seegers H., Étude technique et économique de systèmes laitiers herbagers en Pays de la Loire, $8^{\text {es }}$ Rencontres Recherches Ruminants, 5-6 décembre 2001, Paris, pp. 237-244.

[4] Carrique Mas J.J., Widdowson M.A., Cuellar A.M., Ribera H., Walker A.R., Risk of babesiosis and anaplasmosis in different ecological zones of Santa Cruz Department, Bolivia, Vet. Parasitol. 93 (2000) 29-38.

[5] Chauvin A., Valentin A., Malandrin L., L'Hostis M., Sheep as a new experimental host for Babesia divergens, Vet. Res. 33 (2002) 429-433.

[6] Coles G.C., The future of veterinary parasitology, Vet. Parasitol. 98 (2001) 31-39.

[7] Collin E., Anaplasmose bovine: une observation clinique en Bretagne, Point Vét. 29 (1998) 79-80.

[8] Cordonnier P., Économie de la production laitière, Technique et Documentation Lavoisier \& INRA, Paris, 1986, 218 p.

[9] Dedieu B., Servière G., Organisation du travail et fonctionnement des systèmes d'élevage. $8^{\text {es }}$ Rencontres Recherches Ruminants, 5-6 décembre 2001, Paris, pp. 245-250.

[10] Derioz P., Comment quantifier le phénomène du boisement spontané: inventaire des inventaires à l'échelle nationale, Ingénieries - E A T CEMAGREF, $\mathrm{n}^{\circ}$ spécial Boisements naturels des espaces agricoles en déprise, 1999, pp. 11-23.

[11] Donnelly J., Pierce M.A., Experiments on the transmission of Babesia divergens to cattle by the tick Ixodes ricinus, Int. J. Parasitol. 5 (1975) 363-367.

[12] Estrada-Pena A., Forecasting habitat suitability for ticks and prevention of tick-borne diseases, Vet. Parasitol. 98 (2001) 111-132

[13] Friedhoff K.T., Transmission of Babesia, in: Ristic (Ed.), Babesiosis of domestic animals and man, CRC Press, Inc. Boca Raton, Florida, 1988, pp. 23-52.

[14] Geay Y., La production de taurillons, in: Micol D., Production de viande bovine, INRA, Paris, 1986, pp. 151-168

[15] Gilibert J., Hivernage en plein air en élevage bovin viande - constitution d'un référentiel technico-économique, Rapport technique INRA DADP Pays de la Loire, 1998, 48 p.

[16] Gilot B., Bonnefille M., Degeilh B., Beaucournu J.C., Pichot J., Guiguen C., La colonisation des massifs forestiers par Ixodes ricinus (Linné, 1758) en France: utilisation du Chevreuil, Capreolus capreolus (L. 1758) comme marqueur biologique, Parasite 1 (1994) 81-86.

[17] Gilot B., Guiguen C., Degeiglh B., Doche B. Pichot J., Beaucournu J.C., Phytoecological mapping of Ixodes ricinus as an approach to the distribution of Lyme borreliosis in France, in: Axford J.S. (Ed.), Lyme Borreliosis, Plenum Publishing Corporation, 1994, pp. 105-112.

[18] Gorenflot A., Carcy B., Moubri K., Précigout E., Schetters T., Les babésioses humaines, Méd. Mal. Infect., 28 (1998) 363-366.

[19] Guesdon J.C., Bontron J.C., Bourgeois L., Chatellier V., Perrot C., You G., Prospective 2020 dans le secteur européen de l'élevage bovin lait et viande, Le Dossier Économie de l'Élevage, Octobre 2000, Institut de l'Élevage, Paris, $42 \mathrm{p}$

[20] Hillyard P.D., Ticks of North-West Europe, The Linnean Society of London, The Estuarine and Coastal sciences Association, Field Studies Council, Shrewsbury, 1996, 178 p.

[21] Joncour G., Argenté G., Guillou L., Un épisode d'ehrlichiose dans un troupeau laitier, Bulletin des GTV 5 (1999/2000) 309-314.

[22] Kingsnorth P., La déstabilisation de la santé humaine, in: L'Écologiste Vol. 2, No 2, 2000, pp. $45-48$.

[23] Levine N.D., The protozoan phylum apicomplexa, Vol. II, CRC Press, Inc. Boca Raton, Florida, 1988, pp. 35-45.

[24] L'Hostis M., Chauvin A., Valentin A., Marchand A., Gorenflot A., Large scale survey of Babesia divergens bovine babesiosis in France, Vet. Rec. 136 (1994) 36-38.

[25] L'Hostis M., Dumon H., Dorchies B., Boisdron F., Gorenflot A., Seasonal incidence and ecology of the tick Ixodes ricinus (Acari: Ixodidae) on grazing pastures in western France, Exp. Appl. Acarol. 19 (1995) 211-220.

[26] L'Hostis M., Chauvin A., Valentin A., Précigout E., Gorenflot A., A survey of Babesia divergens antibody kinetics in cattle in western France, Vet. Res. 28 (1997) 481-488.

[27] Macleod J., The bionomics of Ixodes ricinus L., the "sheep tick" of Scotland, Parasitology 24 (1932) 382-400.

[28] Mahoney D.F., The application of epizootiological principles in the control of Babesiosis in cattle, Bull. Off. Int. Epizoot. 81 (1974) 123-138.

[29] Mahoney D.F., Ross D.R., Epizootiological factors in the control of bovine babesiosis, Aust. Vet. J. 48 (1972) 292-298. 
[30] Malbert C.H., Pangui L.J., Dorchies P., Ruckebusch Y., Babesia major: abomasal transmural potential difference, and antroduodeal motility changes associated with experimental infection in calf, Ann. Rech. Vét. 19 (1988) 237-243.

[31] Martinez D., Aumont G., Moutoussamy M., Gabriel D., Tatareau A.H., Barré N., Vallée F., Mari B., Epidemiological studies on dermatophilosis in the Caribbean, Rev. Elev. Méd. Vét. Pays Trop. 46 (1993) 323-327.

[32] Mémeteau S., Seegers H., Jolivet F., L'Hostis M., Assessment of the risk of infestation by Ixodes ricinus due to their phyto-ecological characteristics, Vet. Res. 29 (1998) 487-496.

[33] Micol D., La production de viande de bœufs et de jeunes taureaux, in: Micol D., Production de viande bovine, INRA, Paris, 1986, pp. 169-200.

[34] Milne M.A., The ecology of the sheep tick, Ixodes ricinus L. Part 2: Observations on hill and moorland grazing in Northern England, Parasitology 39 (1948) 173-197.

[35] Milne M.A., The ecology of the sheep tick, Ixodes ricinus L. Spatial distribution, Parasitology 40 (1950) 35-45.

[36] Molyneux D.H., Vector-borne parasitic diseases, an overview of recent changes, Int. J. Parasitol. 28 (1998) 927-934.

[37] Morel P.C., Réflexions sur l'épizootiologie de la babésiose bovine européenne à Babesia divergens, Bull. Acad. Vét. Fr. 53 (1980) 451-456.

[38] Perry B.D., Young A.S., The past and future roles of epidemiology and economics in the control of tick-borne diseases of livestock in Africa: the case of theileriosis, Prev. Vet. Med. 25 (1995) 107-120.

[39] Pichon B., Mousson L., Figureau C., Rodhain F., Perez-Eid C., Density of Deer in relation to the prevalence of Borrelia burgdorferi s.l. in Ixodes ricinus nymphs in Rambouillet forest, France, Exp. Appl. Acarol. 23 (1999) 267-275.

[40] Quinqu J., Dynamique structurelle des exploitations laitières françaises au cours de la décennie 90, 7es Rencontres Recherches Ruminants, 6-7 décembre 2000, Paris, pp. 31-34.
[41] SCEES (Service Central des Enquêtes et Études Statistiques), L'Agriculture, la forêt et les industries agroalimentaires, Annuaire GraphAgri 2001, Ministère de l'Agriculture et de la Pêche SCEES, Paris, 2001, 159 p.

[42] Sergent E., Donatien A., Parrot L., Lestoquard F., Plantureaux E., Les piroplasmoses bovines dues aux Babesiella, Étude d'ensemble avec description d'une espèce nouvelle $B$. major, originaire de France, Arch. Inst. Pasteur Algér. 4 (1926) 318-339.

[43] Simitch T., Petrovitch Z., Rakovec R., Les espèces de Babesiella du bœuf d'Europe, Arch. Inst. Pasteur Algér. 33 (1955) 310-314.

[44] Skrabalo Z., Deanovac Z., Piroplasmosis in man, Report on a case, Doc. Med. Geogr. Trop. 9 (1957) 11-16.

[45] Sutherst R.W., Ingram J.S.I., Scherm H., Global change and vector-borne diseases, Parasitol. Today 8 (1998) 297-299.

[46] Thompson R.C.A., The future of veterinary parasitology: a time for change? Vet. Parasitol. 98 (2001) 41-50.

[47] Tirel J.C., L'extensification: chance ou défi pour les exploitations agricoles, INRA Prod. Anim. 4 (1991) 5-12.

[48] Uilenberg G., Tick-borne infections of cattle on Corsica. Newsletter on ticks and tick-borne diseases of livestock in the tropics, No. 14, 2000, p. 13.

[49] Van't Land A., Van lenteren A.C., Van Schooten E., Bouwmans C., Gravesteyn D.J., Hink P., Effects of husbandry systems and the efficiency and optimisation of robotic milking performance and management, in: Hogeveen H., Meijering A., Robotic Milking, Proc. Symposium, Lelystad, Pays-bas, 17-19 August 2000, pp. 167-176.

[50] Vassalo M., Paul R.E., Perez-Eid C., Temporal distribution of the annual nymphal stock of Ixodes ricinus ticks, Exp. Appl. Acarol. 24 (2000) 941-949.

[51] Wikel S.K., Tick modulation of host immunity: an important factor in pathogen transmission, Int. J. Parasitol. 29 (2001) 851-859.

To access this journal online: www.edpsciences.org 